\title{
Efek vitamin D terhadap kadar IL-10, IFN- $\gamma$, dan histamin pada kultur PBMC pasien rinitis alergi
}

\author{
Budi Utama*, Heri Wibowo**, Niken Lestari Poerbonegoro*** \\ *Program Magister Ilmu Biomedik, **Departemen Parasitologi, \\ $* * *$ Departemen Telinga Hidung Tenggorok Bedah - Kepala Leher \\ Fakutas Kedokteran Universitas Indonesia/ \\ Rumah Sakit Umum Pusat Dr. Cipto Mangunkusumo \\ Jakarta
}

\begin{abstract}
ABSTRAK
Latar belakang: Rinitis alergi (RA) adalah penyakit inflamasi pada hidung, yang disebabkan oleh reaksi alergi pada pasien atopi. Tungau debu rumah merupakan aeroalergen yang tersering memicu reaksi alergi. Pada tahun 1988, reseptor vitamin D berhasil dilakukan klon. Reseptor vitamin D berlokasi di beberapa jaringan dan sel tubuh manusia, termasuk di sel-sel darah tepi berinti tunggal (peripheral blood mononuclear cells/PMBC). Tujuan: Mengidentifikasi pengaruh pemberian vitamin D pada selsel darah tepi berinti tunggal penderita rinitis alergi terhadap sel Th1, Th2, dan T Regulator, dengan cara melihat sekresi IFN- $\gamma$, IL-10, dan histamin. Metode: Sampel berupa darah segar (whole blood) penderita rinitis alergi yang telah dilakukan prick test, diolah dengan metode Ficoll untuk mengisolasi sel berinti tunggal. Kultur sel limfosit sebelum perlakuan dibagi menjadi kelompok yang diberi pendedahan dengan 1,25(OH)2D3 $100 \mathrm{nM}$ dan tanpa pendedahan, waktu inkubasi 7 hari, dengan penambahan phytohaemaglutinin dan alergen tungau pada hari ke-4. Kultur sel-sel darah tepi berinti tunggal dari pasien RA setelah perlakuan, selanjutnya pada hari ke-7 supernatannya diambil dan dibagi untuk diukur kadar sitokin IFN- $\gamma$, IL-10, dan histamin secara ELISA. Dilakukan uji secara statistik untuk melihat pola dari tiap parameter. Hasil: Pemberian alergen tungau tanpa vitamin D menyebabkan meningkatnya kadar histamin serta menurunkan kadar IL-10 dan IFN- $\gamma$. Pemberian vitamin D pada kultur sel darah tepi berinti tunggal yang telah diberi alergen tungau, dapat meningkatkan kadar IL-10 dan menurunkan kadar IFN- $\gamma$, serta histamin. Kesimpulan: Menurunnya kadar histamin dan IFN- $\gamma$ terhadap stimulasi alergen tungau pada pasien rinitis alergi yang diberi vitamin D cenderung berhubungan dengan meningkatnya kadar IL-10.
\end{abstract}

Kata kunci: Sel mast, rinitis alergi, tungau debu rumah, vitamin D

\section{ABSTRACT}

Background: Allergic rhinitis is an inflammatory disease of the nose, caused by an allergic reaction in atopic patients. House dust mites are the most common aeroalergen. In 1988, vitamin D receptor had been cloned successfully. Vitamin D receptors are located in various tissues and human body cells, including peripheral blood mononuclear cells (PBMCs). Purpose: To identify the effect of vitamin D on peripheral blood mononuclear cells culture of allergic rhinitis patients towards Th1, Th2, and T Regulator cell, by identifying IL-10, IFN- $\gamma$, and histamine secretion levels. Method: The sample were obtained from fresh blood (whole blood) of allergic rhinitis patients who had been prick tested, and isolated by Ficoll method. Pre-treated lymphocyte culture divided into groups treated with and without 1,25(OH)2D3 100 $n M$, and incubated for 7 days, with addition of phytohaemaglutinin and allergen mites on day 4. Cultures of PBMC cells after treatment were harvested on day 7 , then the supernatant was dialyzed to measure the levels of IFN- $\gamma$ IL-10 and histamine cytokines. Statistical test was performed to identify patterns of each parameter. Results: Treatment of allergen mites without vitamin D could increase levels of histamine and lower levels of IL-10 and IFN- $\gamma$. Provision of vitamin D in PBMC cell culture that had been given allergen mites could increase levels of $I L-10$ and decreased levels of $I F N-\gamma$ and histamine. Conclusion: Lower levels of histamine and IFN- $\gamma$ against allergen mite stimulation of allergic rhinitis patients who were given vitamin $D$ tend to be associated with increased IL-10 levels. 
Keywords: Mast cell, allergic rhinitis, house dust mite, vitamin D

Alamat korespondensi: Dr. Budi Utama. Fakultas Kedokteran Universitas Indonesia. Rumah Sakit Umum Pusat Dr. Cipto Mangunkusumo, Jakarta.

\section{PENDAHULUAN}

Rinitis alergi (RA) adalah penyakit inflamasi pada hidung, yang disebabkan oleh reaksi alergi pada pasien atopi yang sebelumnya sudah tersensitisasi dengan alergen yang sama, serta dilepaskannya suatu mediator kimia ketika terjadi paparan ulang dengan alergen spesifik tersebut. Menurut WHO-ARIA (World Health Organization Allergic Rhinitis and Impact on Asthma) RA adalah kelainan pada hidung dengan gejala bersin-bersin, rinore, rasa gatal dan tersumbat setelah mukosa hidung terpapar alergen yang diperantarai IgE. ${ }^{1}$

Tungau debu rumah merupakan aero allergen tersering yang memicu reaksi alergi. Dermatophagoides pteronyssinus (Der $\mathrm{p}$ ) dan Dermatophagoides farinae (Der f) memproduksi lebih dari 20 macam alergen yang dibedakan berdasarkan sekuens asam amino dan fungsi biologi. ${ }^{2}$

Sel T penolong ( $T$ helper/Th) dalam memproduksi sitokin, berdiferensiasi menjadi dua subset berdasarkan profil sitokin yang dikeluarkan, yaitu Th1 dan Th2. Dikenal pula akhir-akhir ini adanya subset Th3. Sel Th disebut Th1 bila memproduksi sitokin IFN- $\gamma$, IL-2, TNF- $\alpha$ dan Th2 bila mengeluarkan IL-4, IL-5, IL-10 dan IL-13. Perbedaan pola sitokin ini berhubungan dengan fungsi spesifik yaitu sel Th1 terlibat di dalam reaksi hipersensitivitas lambat, delayed type hipersensitivity $(D T H)$ atau imunitas seluler sedangkan Th2 penting untuk terjadinya respons antibodi atau imunitas humoral, terutama dalam sintesis $\mathrm{IgE}$.

Th1 dan Th2 selalu berada dalam keseimbangan dan hal ini dikenal sebagai paradigma Th1/Th2. Polarisasi ke arah Th1 atau Th2 bergantung pada berbagai faktor transkripsi yang diaktivasi maupun lingkungan mikro dan sitokin dalam lingkungan itu, khususnya IL-12 atau IFN- $\gamma$ atau IL-4. ${ }^{3}$

Populasi sel CD4+ yang kemudian karena memproduksi sitokin IL-17 disebut sel Th17. Faktor transkripsi penting untuk perkembangan sel Th17 adalah retinoic acid related orphan receptor (ROR $\gamma \mathrm{T})$. Sel ini terbukti berasal dari induk yang sama dengan sel T reg (CD+Foxp3+) dan keduanya diproduksi sebagai respon terhadap TGF- $\beta$, tetapi polarisasi ke arah Th17 hanya terjadi kalau secara simultan juga diproduksi IL- $6 .{ }^{4}$

Pada tahun 1988 vitamin $D$ receptor (VDR), berhasil dilakukan klon. ${ }^{3}$ Reseptor vitamin $\mathrm{D}$ berlokasi di beberapa jaringan dan sel tubuh manusia, termasuk di peripheral blood mononuclear cells (PBMCs) dan limfosit $\mathrm{T}$ yang telah teraktivasi. Selain itu VDR juga berlokasi pada sel dendritik, merupakan antigen-presenting cell (APC) penting. ${ }^{5}$

Vitamin D merupakan hormon steroid dengan reseptor di nukleus (nuclear receptor). Nuclear receptor mempunyai kemampuan untuk mengikat DNA secara langsung dan

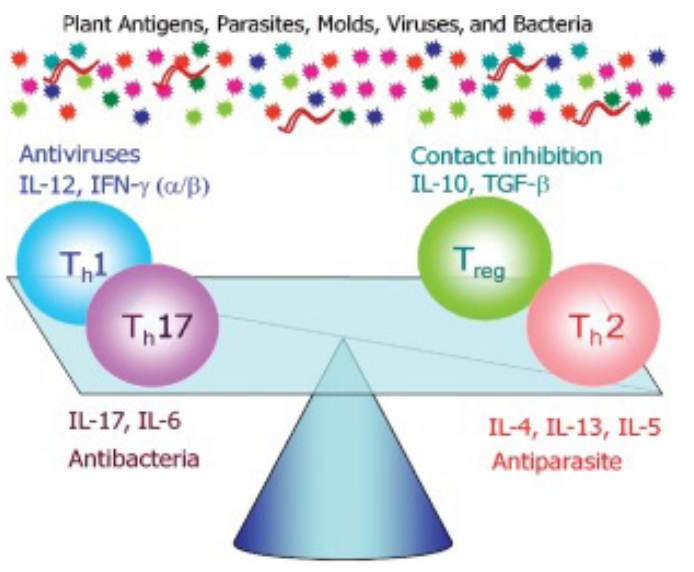

Gambar 1. Model keseimbangan segi empat. Tipe sel $\mathrm{T}$ (Th1, Th1, Th17, dan T reg) saling antagonis satu sama lain. 
mengatur ekspresi dari gen yang terikat, sehingga reseptor ini termasuk dalam kelompok faktor transkripsi. Reseptor ini bersama dengan faktor transkripsi lainnya akan mengatur transkripsi gen spesifik, yang pada akhirnya dapat mengontrol perkembangan, homeostasis, dan metabolisme organisme. Nuclear receptor mempunyai 6 domain (domain A sampai F). Salah satu domain berfungsi sebagai ligan binding domain (LBD) yang akan berikatan dengan ligannya. Selain LBD terdapat DNA Binding Domain (DBD), yang akan berikatan dengan sekuens DNA sel target pada daerah yang disebut hormone response elements (HRE). ${ }^{6}$

Semua organ target vitamin $\mathrm{D}$, termasuk selimun, memiliki VDR pada inti selnya. Vitamin D dalam bentuk aktif berupa 1,25(OH)2D2 akan berikatan dengan VDR membentuk kompleks 1,25(OH)2DVDR. Kompleks 1,25(OH)2D-VDR akan berinteraksi dengan retinoic acid $X$ receptor (RXR) membentuk heterodimer yang kemudian akan berinteraksi dengan vitamin D-responsive element (VDRE) pada deoksiribonucleic acid (DNA). Interaksi ini akan menghasilkan sintesis messenger ribonucleic acid (mRNA) baru, yang pada akhirnya mengontrol perkembangan, homeostasis, dan metabolisme sel target. Bagian VDR yang berikatan dengan $1,25(\mathrm{OH}) 2 \mathrm{D} 2$ adalah pada daerah terminal $\mathrm{C}$, yang disebut hormone binding domain, sedangkan bagian yang berikatan dengan DNA adalah pada daerah terminal $\mathrm{N}$, yang disebut DNA binding domain yang memiliki jari-jari Z. Vitamin D mungkin juga dapat menghambat proliferasi sel $\mathrm{B}$ dan juga menghambat sel B.?

Tujuan penelitian ini adalah mengidentifikasi pengaruh pemberian vitamin D pada sel-sel darah tepi berinti tunggal penderita rinitis alergi terhadap sel Th1, Th2, dan T Regulator, dengan cara melihat sekresi IFN- $\gamma$, IL-10, dan histamin.

\section{METODE}

Sampel diambil dari darah segar (whole blood) penderita rinitis alergi yang diagnosisnya ditegakkan oleh Ahli Telinga Hidung Tenggorok berdasarkan anamnesis dan pemeriksaan fisik. Hasil diagnosis tersebut diperkuat dengan skin prick test untuk menentukan alergen yang spesifik. Dipilih penderita yang mempunyai hasil skin prick test yang positif untuk tungau. Kriteria eksklusi adalah apabila penderita mengalami demam serta infeksi sekunder.

Ekstrak tungau debu rumah total Der $\mathrm{f}$ diperoleh dari kultur tungau yang disediakan Pusat Penelitian Siriraj Dust Mite, Departemen Parasitologi, Fakultas Kedokteran Rumah Sakit Siriraj, Universitas Mahidol, Thailand.

Isolasi PBMC dilakukan dengan cara mengambil darah sebanyak $6 \mathrm{~mL}$, kemudian menambah dengan $6 \mathrm{~mL}$ stok medium Roswell Park Memorial Institute (RPMI), setelah itu dihomogenkan menggunakan pipet. Menyiapkan tabung steril $15 \mathrm{~mL}$ yang telah diisi dengan 5 $\mathrm{mL}$ Ficoll. Secara hati-hati darah yang telah diencerkan kemudian dimasukkan ke larutan Ficoll, lalu disentrifugasi dengan kecepatan 400 g selama 30 menit. Lapisan yang paling atas yang berisi plasma dibuang dengan menggunakan pipet sampai lapisan buffycoat.

Lapisan buffycoat yang berisi PBMC diambil dan dipindahkan ke tabung steril $15 \mathrm{~mL}$ yang baru. Ditambahkan Phosphate buffer saline (PBS) sejumlah $5 \mathrm{~mL}$ untuk proses pencucian PBMC serta dihomogenkan dengan pipet. Kemudian dilakukan sentrifugasi kembali dengan kecepatan $100 \mathrm{~g}$ selama 10 menit. Supernatan dibuang dan ditambahkan $2 \mathrm{~mL}$ medium lengkap yang dibuat dengan komposisi $10 \%$ plasma autolog, $1 \%$ penisilinstreptomisin, dan 89\% RPMI 1640 (Gibco) ke atas palet sel, kemudian diresuspensi kembali. Dilakukan perhitungan sel dengan cara $10 \mu \mathrm{L}$ suspensi PBMC di atas ditambahkan dengan 10 $\mu \mathrm{L}$ tryphan blue, lalu dihomogenkan. Diambil $10 \mu \mathrm{L}$ campuran sel tersebut dan dihitung menggunakan bilik hitung. 
Disiapkan 6 sumur (24 multiwell plate), kemudian dimasukkan PBMC sejumlah 500.000 sel ke dalam tiap-tiap sumur yang telah disiapkan dalam plate. Ke dalam 3 sumur diberikan 1,25(OH)2D3 sejumlah $100 \mathrm{nM}$ dan 3 sumur lagi tanpa 1,25(OH)2D3. Plate dimasukkan ke dalam inkubator suhu $37^{\circ} \mathrm{C}, \mathrm{CO}_{2} 5 \%$ selama 3 hari. Setelah 3 hari dilakukan stimulus dengan menambahkan alergen tungau sebanyak 100 $\mu \mathrm{g} / \mathrm{ml}$ pada medium RPMI. Medium RPMI tanpa alergen tungau sebagai kontrol negatif, serta medium RPMI dengan penambahan phytohaemaglutinin (PHA) $10 \mu \mathrm{g} / \mathrm{mL}$ sebagai kontrol positif. Selanjutnya kultur kembali diinkubasi selama 3 hari pada $37^{\circ} \mathrm{C} \mathrm{CO}_{2} 5 \%$. Pada hari ke-6 supernatan diambil dan dialikuot (dibagi dalam jumlah tertentu) ke dalam beberapa tabung Eppendorf dan disimpan pada suhu $-80^{\circ} \mathrm{C}$ sampai dengan pemeriksaan ELISA (Enzyme-linked immunosorbent assay).

Pada penelitian ini akan dilakukan pengukuran IL-10, IFN- $\gamma$, dan histamin pada medium dari masing-masing perlakuan. Pengukuran menggunakan uji ELISA dengan human kit $R \& D$ system dengan langkah sesuai petunjuk pada kit. Setelah semua tahapan pemeriksaan ELISA selesai, dilakukan pembacaan menggunakan ELISA Vmax Rreader dengan cara membaca densitas optik tiap sumur dengan menggunakan gelombang $450 \mathrm{~nm}$ dan $540 \mathrm{~nm}$ sebagai koreksi. Hasil bacaan densitas optik dari larutan standar dan konsentrasi larutan

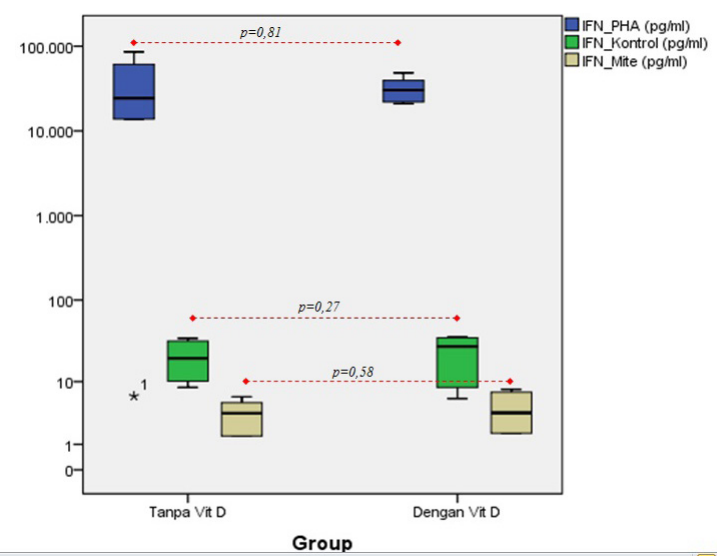

Gambar 2. Grafik produksi IFN- $\gamma$ dari kultur PBMC dengan dan tanpa vitamin $\mathrm{D}$ yang distimulasi oleh PHA (kontrol+), RPMI (kontrol -) dan alergen tungau. standar dibuat kurva standar. Konsentrasi IL10 dan IFN- $\gamma$ dalam sampel diperoleh dengan mengekstrapolasi nilai densitas optik masingmasing sampel berdasarkan kurva standar tersebut.

Pada penelitian ini digunakan analisis univariat dan bivariat pada sitokin IL-10, IFN- $\gamma$, dan histamin antara sebelum dan sesudah suplementasi. Uji statistik menggunakan uji $\mathrm{t}$ berpasangan bila distribusi normal dan uji Wilcoxon bila data tidak normal. Untuk mengetahui hubungan antara variabel independen yaitu suplementasi vitamin D dan alergen tungau serta variabel dependen (kadar IL-10, IFN- $\gamma$, dan histamin) digunakan uji korelasi Pearson untuk data berdistribusi normal, dan uji korelasi Spearman untuk data berdistribusi tidak normal.

\section{HASIL}

Efek pemberian vitamin D pada kultur PBMC yang berasal dari 6 subyek penderita rinitis dilakukan secara in vitro dengan stimulasi PHA (kontrol +), RPMI (kontrol-), dan alergen tungau. Efek pemberian vitamin D pada kultur PBMC dinilai berdasarkan kemampuannya dalam memproduksi sitokin proinflamasi IFN- $\gamma$ dan antiinflamasi IL-10, serta potensi sel PBMC dalam memproduksi histamin setelah diberikan stimulasi alergen tungau.

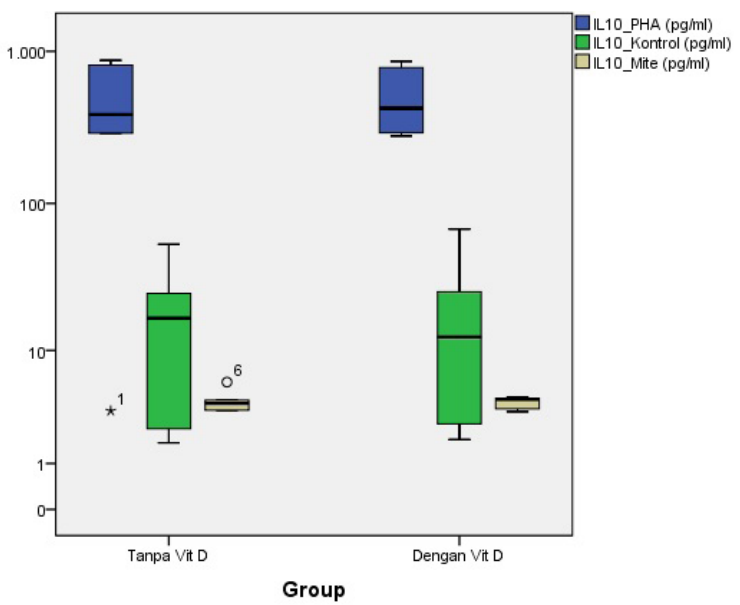

Gambar 3. Grafik produksi IL-10 dari kultur PBMC dengan dan tanpa vitamin $\mathrm{D}$ yang distimulasi oleh PHA (kontrol+), RPMI (kontrol) dan alergen tungau. 
Kadar IFN- $\gamma$ kultur PBMC yang distimulasi oleh PHA, RPMI, dan alergen tungau dengan ada dan tidak ditambahkan vitamin D

Hasil pengukuran kadar IFN- $\gamma$ kultur PBMC yang distimulasi oleh PHA, RPMI, dan tungau pada kultur yang dengan dan tidak ditambahkan vitamin D tertera pada gambar 2 .

\section{Kadar IL10 kultur PBMC yang distimulasi oleh PHA, RPMI, dan tungau dengan dan tidak ditambahkan vitamin $D$}

Hasil pengukuran kadar IL-10 kultur PBMC yang distimulasi oleh PHA, RPMI dan alergen tungau pada kultur yang dengan ada dan tidak ditambahkan vitamin D tertera pada gambar 3.

Gambar 2 dan 3 menunjukkan bahwa pemberian PHA baik pada kelompok dengan dan tanpa vitamin D menghasilkan IL-10 tertinggi dibanding kontrol dan tungau. Stimulasi dengan tungau menghasilkan produksi IL-10 terendah. Tidak terdapat perbedaan bermakna stimulasi PHA, kontrol, dan tungau pada kultur PBMC dengan dan tanpa vitamin $\mathrm{D}$.
Efek pemberian vitamin D pada kultur PBMC terhadap pola perubahan produksi IFN- $\gamma$ dan IL-10 sebagai respons terhadap alergen tungau

Untuk mengidentifikasi efek pemberian vitamin $\mathrm{D}$ terhadap perubahan karakter kultur sel PBMC dalam produksi sitokin IFN- $\gamma$ dan IL-10 sebagai respons adanya alergen tungau, dilakukan analisis terhadap IFN- $\gamma$ dan IL-10 dari kultur PBMC yang distimulasi dengan alergen tungau sebelum dan sesudah pemberian vitamin D. Gambar 4 menunjukkan perubahan karakter sel dibandingkan pada saat sel kontrol (hanya ditambahkan RPMI) dan setelah diberikan induksi alergen tungau.

Berdasarkan tabel 1 tampak bahwa kultur PBMC yang produksi IL-10 terhadap alergen tungau yang dikategorikan tinggi sebelum pemberian vitamin D sebesar $33,3 \%$ mengalami peningkatan menjadi $66,7 \%$ setelah diberikan vitamin $\mathrm{D}$ dalam kultur PBMC nya. Produksi IFN- $\gamma$ yang dikategorikan tinggi mengalami penurunan dari semula $50 \%$ menjadi $33,3 \%$ pasca pemberian vitamin D. Sebaliknya, kultur PBMC pasca pemberian vitamin D didominasi oleh produksi IFN- $\gamma$ yang dikategorikan rendah $(66,7 \%)$.

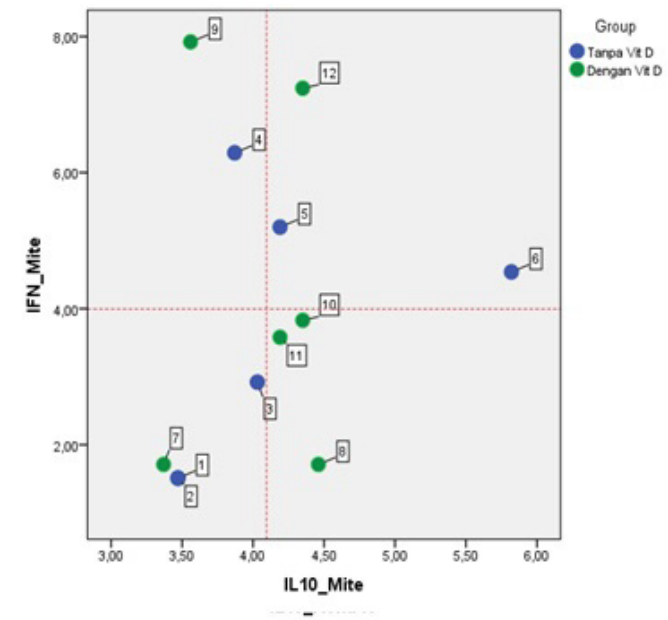

Gambar 4. Grafik scater produksi IFN- $\gamma$ dan IL-10 dari kultur PBMC dengan dan tanpa vitamin D pada kontrol (RPMI) (kiri), dan setelah ditambahkan alergen tungau (kanan). 
Tabel 1. Hubungan antara kadar IL-10 dengan IFN- $\gamma$ pada kultur PBMC yang distimulasi alergen tungau

\begin{tabular}{lrrrr}
\hline & & IL-10 & & \multicolumn{2}{c}{ IFN - $\gamma$} & \\
\hline & Tinggi & Rendah & Tinggi & Rendah \\
\hline Tanpa & & & & \\
vitamin D & 2 & 4 & 3 & 3 \\
N & 33,3 & 66,7 & 50 & 50 \\
$\%$ & & & & \\
\hline Dengan & 4 & 2 & 2 & 4 \\
vitamin D & 66,7 & 33,3 & 33,3 & 66,7 \\
N & & & & \\
$\%$ & & & & \\
\hline
\end{tabular}

Stimulasi alergen pada kultur PBMC dari darah subyek rinitis alergi yang semula sebagian besar cenderung menghasilkan IL10 yang rendah. IFN- $\gamma$ yang tinggi setelah kultur PBMC ditambahkan vitamin D mengalami perubahan yang sebagian besar menghasilkan IL-10 yang tinggi dan IFN- $\gamma$ yang rendah.

Efek pemberian vitamin D pada kultur PBMC yang distimulasi alergen tungau terhadap produksi histamin

Hasil analisis korelasi antara IL-10 dengan histamin dari kultur PBMC yang distimulasi alergen tungau dengan dan tanpa vitamin D menunjukkan pola korelasi yang berbeda seperti tertera pada gambar 5. Hubungan IL-10 dan produksi histamin

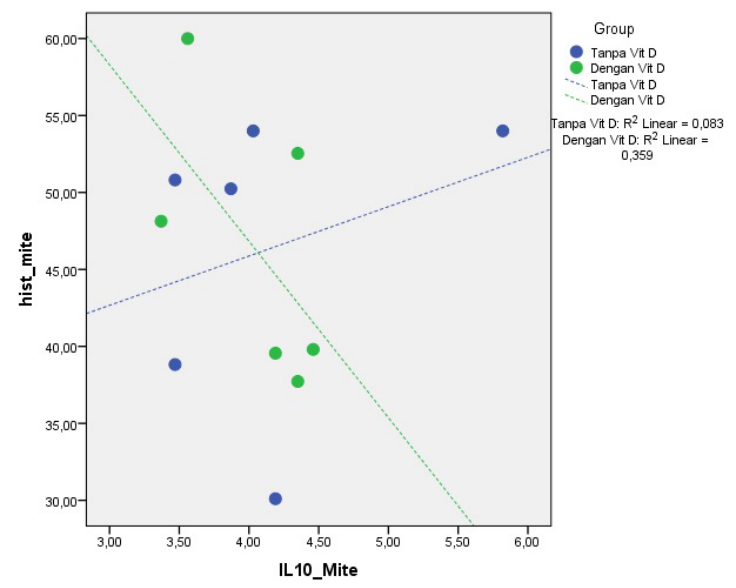

Gambar 5. Korelasi antara IL-10 dengan produksi histamin pada kultur PBMC yang distimulasi alergen tungau pada kelompok kultur PBMC dengan dan tanpa vitamin D. pada kultur PBMC yang diberi viamin D menunjukkan korelasi negatif. Semakin tinggi kadar IL-10, semakin rendah kadar histamin yang diproduksi $(r=-0,6 ; p=0,10)$. Namun demikian, korelasi ini tidak cukup signifikan. Sebaliknya pada kelompok yang tidak diberi vitamin D hubungan IL-10 dengan produksi histamin menunjukkan pola korelasi positif. Semakin tinggi kadar IL-10 cenderung menyebabkan kenaikan produksi histamin. Akan tetapi, korelasi positif ini juga tidak cukup signifikan $(r=0,28 ; p=0,29)$

\section{DISKUSI}

Pada penelitian ini, efek vitamin D pada kondisi fisiologis yaitu $100 \mathrm{nM}$ yang diberi paparan alergen tungau sejumlah $100 \mu \mathrm{g} / \mathrm{ml}$ pada supernatan sel-sel PBMC penderita rinitis alergi.

\section{Pemberian alergen tungau pada supernatan sel PBMC penderita rinitis alergi tanpa pemberian vitamin $D$ dapat menurunkan produksi IL-10 dan IFN- $\gamma$}

Alergen tungau berasal dari tungau debu rumah yang bagi sekelompok orang merupakan komponen alergen hirup yang penting dalam memicu reaksi alergi termasuk rinitis alergi. Tungau debu rumah merupakan organisme yang kompleks dengan variasi protein yang dapat merangsang antibodi $\mathrm{IgE}$ pada individu yang poten. Sel Th2 mempunyai peranan yang penting untuk terjadinya sintesis 
IgE sehingga akan terjadi peningkatan sitokin IL-4, IL-5, IL-10, dan IL-13. Pada penyakit atopi terjadi polarisasi ke arah Th1/Th2 bergantung pada berbagai faktor transkripsi teraktivasi maupun sitokin dalam lingkungan tersebut, khususnya IL-12, IFN- $\gamma$, atau IL4. Keberadaan Th1 memerlukan paparan IFN- $\gamma$ untuk mempertahankan reseptor IL12, sedangkan IL-4 menghambat reseptor IL-12. Mekanisme ini juga tercermin dalam mekanisme regulasi faktor transkripsi T-bet yang merupakan faktor penentu untuk galur Th1 secara fisik berintraksi dan menghambat GATA-3 yang merupakan faktor transkripsi untuk Th2. ${ }^{8}$

Pada penelitian ini terlihat bahwa penurunan IL-10 pada kedua kelompok kontrol dan perlakuan tidak bermakna secara signifikan. Secara umum terjadi penurunan IL-10 dan IFN- $\gamma$ (gambar 2). Hal ini sesuai dengan penelitian Imada $\mathrm{dkk}^{9}$ yang mengatakan pemberian serbuk sari pada pasien rinitis alergi menyebabkan peningkatan kadar IL-4 dan penurunan kadar IFN- $\gamma$. Sedangkan pada orang yang non atopi terjadi perbandingan yang terbalik.

\section{Pemberian PHApada supernatan sel PBMC penderita rinitis alergi meningkatkan produksi IL-10 dan IFN- $\gamma$}

Fungsi PHA disini merupakan kontrol positif. Seperti diketahui PHA merupakan suatu protein lektin yang dapat berikatan dengan membran sel $\mathrm{T}$ dan menstimulasi aktivitas metabolik, pembelahan sel, dan lain-lain. Subunit PHA terdiri dari 2 tipe, yaitu reaktif leukosit dan reaktif limfosit. Sebagai mitogen, digunakan secara luas untuk stimulasi mitosis dari sel limfosit, dan beberapa tipe seperti PHA-P, M, W dan lainnya telah digunakan. ${ }^{10}$

Pada penelitian ini tampak pada pemberian $10 \mu \mathrm{g} / \mathrm{ml}$ PHA dapat menstimulasi sel limfosit dengan ditandai peningkatan dari produksi sitokin IL-10 dan IFN- $\gamma$. Kultur sel
PBMC yang telah diberi $10 \mu \mathrm{g} / \mathrm{ml}$ PHA serta ditambahkan dengan vitamin $\mathrm{D}$, kadar sitokin IL-10, dan IFN- $\gamma$ meningkat. Walaupun pada peningkatan kadar IFN- $\gamma$ tidak bermakna secara signifikan $(p=0,129)$. Hal ini memberi kesimpulan bahwa telah terjadi peningkatan kadar sitokin IL-10 dan IFN- $\gamma$, yang berarti sel-sel yang dikultur tumbuh dengan baik.

\section{Efek pemberian alergen tungau pada kultur sel PBMC yang telah diberi vitamin D dan dibanding dengan tanpa diberikan vitamin D}

Sebelum pemberian alergen tungau pada kultur yang tidak dipaparkan vitamin $\mathrm{D}$ dan kultur yang telah dipaparkan vitamin D terlihat bahwa kadar IL-10 kadar IFN- $\gamma$ tidak banyak berubah. Hal ini berbeda dengan kultur sesudah pemberian alergen tungau. Terlihat bahwa kadar IL-10 cenderung tinggi, sementara kadar IFN- $\gamma$ cenderung rendah. Hal ini memperlihatkan bahwa walaupun hasilnya tidak signifikan, namun memang terjadi hubungan yang terbalik antara sebelum dan sesudah pemberian vitamin D pada kultur sel PBMC yang telah dipaparkan dengan alergen tungau. Jadi tidak bisa dipungkiri bahwa pemberian vitamin D mempunyai efek terhadap kadar IL-10 dan IFN- $\gamma$. Hal ini sesuai dengan hipotesis semula dan tampaknya peranan IL-10 lebih besar dibanding IFN- $\gamma$. Peran sel $\mathrm{T}$ regulator menjadi kelihatannya lebih dominan. Pada gambar 4 tampak distribusi penyebaran kadar IL-10 dan IFN- $\gamma$ sebelum diberikan vitamin $\mathrm{D}$ dan alergen tungau, serta sesudah diberikan alergen tungau dan vitamin D. Sebelum diberikan alergen tungau dan vitamin D, kadar IL-10 cenderung lebih rendah dari kadar IFN- $\gamma$. Akan tetapi setelah diberi alergen tungau dan vitamin $\mathrm{D}$ tampak penurunan kadar IFN- $\gamma$ yang tidak diimbangi dengan penurunan IL10 yang memperlihatkan dominannya sel $\mathrm{T}$ regulator (IL-10). 


\section{Efek pemberian vitamin D terhadap kadar histamin sebelum dan sesudah pemberian TDR}

Seperti diketahui histamin merupakan mediator kimia penting yang berperan terhadap patogenesis rinitis alergi. Histamin merupakan hasil degranulasi (pecahnya dinding sel mast). Reseptor sel mast akan mengikat IgE. Hasil cross linking kedua rantai IgE yang mengikat alergen spesifik akan menyebabkan degranulasinya sel mast. IgE diproduksi oleh limfosit B karena teraktivasinya $\mathrm{Th} 2$ sehingga menghasilkan IL-3, IL-4, IL-5, IL-13. Pada pelitian ini stimulus alergen tungau pada sel PBMC penderita rinitis alergi meningkatkan kadar histamin Pemberian vitamin D menurunkan kadar histamin, sejalan dengan meningkatnya kadar IL-10.

Pemberian vitamin D pada kultur sel PBMC pasien rinitis alergi yang distimulasi alergen tungau dapat menurunkan kadar INF- $\gamma$ dan meningkatkan kadar IL-10. Pemberian vitamin D pada kultur sel PBMC pasien rinitis alergi yang distimulasi alergen tungau cenderung menurunkan produksi histmin. Menurunnya kadar histamin terhadap stimulasi alergen tungau pasien rinitis alergi yang diberi vitamin $\mathrm{D}$ cenderung berhubungan dengan meningkatnya kadar IL-10.

\section{DAFTAR PUSTAKA}

1. Nina I, Elise K, Nikmah R. Rinitis alergi. Dalam: Efiaty AS, Nurbaiti I, Jenny B, Ratna $\mathrm{DR}$, editors. Buku ajar ilmu kesehatan telinga hidung tenggorok kepala \& leher. 7 ed. Jakarta: Badan Penerbit Fakultas Kedokteran Universitas Indonesia; 2012; 106-12.

2. Thomas WR, Smith WA, Hales BJ, Milis KL, O'Brien RM. Characterization and immunobiology of house dust mite allergens. Int Arch Allerg Immunol. 2002; 129:1-18.
3. Harijono, KS. Peran Interleukin 12 pada pengalihan respon imun Th2 ke Th1 pada dermatitis atopik. Studi in vitro paparan tungau debu rumah and IL-12 pada kultur Limfosit penderita dermatitis atopik. Disertasi, Program Pasca Sarjana Universitas Airlangga Surabaya, 2003.

4. Romagnani S. Human Th17 cella: Arthr Res Ther 2008; 10: 206. Diunduh dari; http:// arthritisresearch.com/content/20/2/206.

5. Brennan A, Katz DR, Nun JD, et al. Dendritic cells from human tissue express receptors for the immunoregulatory vitamin D3 metabolic, dihydroxycholecalciferol. Immunology. 1987 61(4):457-61.

6. Chen KS, DeLuca HF. Cloning of the human 1 alpha, 25-dihydroxyvitamin D-3 24-hydroxylase gene promoter and identification of two vitamin D-responsive elements. Biochim Biophys Acta. 1995; 1263(1):1-9.

7. ChenS, Sim GP, Chen XX, Gu YY, Chen S, Lipsky PE. Modulatory effect of 1,25 Dyhydroxyvitamin D3 on B Human cell Differentiation. The Journal of Immunology. 2007:179(3); 1634-47.

8. Basso AS, Cheroutre H, Mucida D. More stories on Th 17 cells, Cell Research 2009. 19:399-411.

9. Imada M, Estelle F, Simonst F R, Jay T\& hayglass K. T. 1lergen-stimulated interleukin- 4 and interferon- $\gamma$ production in primary culture: responses of subjects with allergic rhinitis and normal controls ,Blackwellscience Ltd, Imunology, 85, 373-80.

10. Movafagh A, Heydary H, MortazeviTabatabaci SA, Azargash E. The significance application of indigenous Phytohemaglutinin (PHA) mitogen on metaphase and cell culture procedure. Iranian journal of pharmacotical research 2011: 10(4) 895-903. 